\title{
A 15-min non-competitive homogeneous assay for microcystin and nodularin based on time-resolved Förster resonance energy transfer (TR-FRET)
}

\author{
Sultana Akter ${ }^{1}$. Urpo Lamminmäki ${ }^{1}$
}

Received: 28 February 2021 / Revised: 19 April 2021 / Accepted: 26 April 2021 / Published online: 3 June 2021

(C) The Author(s) 2021

\begin{abstract}
Simple and rapid methods are required for screening and analysis of water samples to detect cyanobacterial cyclic peptide hepatotoxins: microcystin/nodularin. Previously, we reported a highly sensitive non-competitive heterogeneous assay for microcystin/nodularin utilizing a generic anti-immunocomplex (anti-IC) single-chain fragment of antibody variable domains $(\mathrm{scFv})$ isolated from a synthetic antibody library together with a generic adda $((2 \mathrm{~S}, 3 \mathrm{~S}, 4 \mathrm{E}, 6 \mathrm{E}, 8 \mathrm{~S}, 9 \mathrm{~S})-3$-amino-9-methoxy-2,6,8trimethyl-10-phenyldeca-4,6-dienoic acid)-specific monoclonal antibody (Mab) recognizing the common adda part of the microcystin/nodularin. Using the same antibody pair, here we report a homogeneous non-competitive assay for microcystin/ nodularin based on TR-FRET (time-resolved Förster resonance energy transfer) measurement. The anti-IC scFv labeled with Alexa Fluor 680 and the Mab labeled with europium enabled the FRET process to occur in the presence of microcystin/nodularin. The TR-FRET signal is proportional to the toxin concentration in the sample. The rapid $(15 \mathrm{~min})$ homogeneous assay without requiring any washing step detected all the tested nine toxin variants (microcystin-LR, -dmLR, -RR, -dmRR, -YR, -LY, -LF $\mathrm{LW}$, and nodularin-R). Very good signal to blank ratio $(\sim 13)$ was achieved using microcystin-LR and the sample detection limit (blank+3SD of blank) for microcystin-LR was $\sim 0.3 \mu \mathrm{g} / \mathrm{L}(\sim 0.08 \mu \mathrm{g} / \mathrm{L}$ in $80-\mu \mathrm{L}$ reaction well). The practical application of the TR-FRET assay was demonstrated with water samples spiked with microcystin-LR as well as with environmental water. The average recoveries of microcystin-LR from spiked water ranged from 65 to $123 \%$. Good correlation $\left(r^{2}=0.73\right.$ to 0.99$)$ with other methods (liquid chromatography-mass spectrometry and previously reported heterogeneous assay) was found when environmental samples were analyzed. The developed wash-free assay has the potential to play as a quick screening tool to detect microcystin/nodularin from water below the World Health Organization's guideline limit ( $1 \mu \mathrm{g} / \mathrm{L}$ of microcystin-LR).
\end{abstract}

Keywords Cyanobacteria - Cyclic peptide hepatotoxin - Environmental contaminant - Fluorescence resonance energy transfer . Sandwich immunoassay $\cdot$ Immunocomplex antibodies $\cdot$ Immune complex antibodies $\cdot$ Hapten

\section{Introduction}

Toxic cyanobacterial blooms create local and global problems by contaminating the surface water resources with their potent toxins commonly known as cyanobacterial toxins or cyanotoxins. Microcystins and nodularins are the most

Published in the topical collection Analytical Applications of Biomimetic Recognition Elements with guest editors Maria C. Moreno-Bondi and Elena Benito-Peña.

Urpo Lamminmäki

urplammi@utu.fi

1 Biotechnology, Department of Life Technologies, Faculty of Technology, University of Turku, 20520 Turku, Finland commonly reported and troublesome cyanobacterial hepatotoxin having negative effect on animal and human health. Microcystins are also classified as possibly carcinogenic to humans [1]; chronic exposure to trace amounts of toxins has been connected to increased risk of hepatocellular carcinoma [2]. Altogether, microcystins and nodularins have been attributed as causative agents for various animal poisonings and identified as a threat for human health [3-5].

Though microcystins are found in freshwater bodies of all over the world and nodularins in predominantly less salty coastal brackish water (e.g., the Baltic Sea, coastal water of Southern Australia) [6], they share structure similarities. Both are monocyclic peptides; microcystins are composed of seven amino acids while nodularins are composed of five amino acids. An unusual $\beta$-amino acid adda ((2S,3S,4E,6E, 8S,9S)- 
3-amino-9-methoxy-2,6,8-trimethyl-10-phenyldeca-4,6dienoic acid), which is essential for toxicity, is present in both microcystins and nodularins among with few other amino acid similarities. Structural variation occurs in both of them; however, it is much more prevalent in microcystins than in nodularins. Until now, over 250 microcystin congeners are reported in the literature along with about 10 congeners of nodularin $[7,8]$. However, in the natural environment, many of these variants are present in minute quantities among the frequently reported microcystin congeners, such as microcystin-LR, -RR, -YR- LA, -WR, and dimethyl microcystin-LR, -RR depending on the geographical distribution $[6,9]$. Microcystin-LR is the most commonly reported and widely distributed toxic microcystin variant. For nodularins, nodularin- $\mathrm{R}$ is the most dominant variant [10].

In 1998, WHO (World Health Organization) recommended a provisional guideline value of $1 \mu \mathrm{g} / \mathrm{L}$ of microcystin-LR in drinking water [11]. Recently, WHO revised the provisional guideline values of microcystin in drinking water and included recommended guideline values for recreational water. The guideline values for lifetime drinking water, short-term drinking water, and recreational water are $1 \mu \mathrm{g} / \mathrm{L}, 12 \mu \mathrm{g} / \mathrm{L}$, and $24 \mu \mathrm{g} / \mathrm{L}$ of microcystin-LR equivalent [9]. WHO recommends that the public should be informed about cyanobacterial blooms in source waters when the water is used for recreation or for producing drinking water [9]. Simple and efficient methods for sensitive and quick screening within or below the WHO guideline level $(1-24 \mu \mathrm{g} / \mathrm{L}$ of microcystin-LR equivalent for drinking water) are particularly in high demand.

Until now, there is no single analysis method sufficient alone for cyanotoxin monitoring. Existing analytical methods such as high-performance liquid chromatography (HPLC) or mass spectrometry (MS) are time consuming, expensive, and require expertise. Some methods (mouse bioassay) are cumbersome and involve animal sacrifice, and many lack specificity and sensitivity (protein phosphatase inhibition assays, PPIAs) [12]. Immunoassays with sufficient sensitivity and specificity are a promising alternative method for microcystin/nodularin detection. Immunoassays are simple and easy to perform, and raw water can be directly applied to the assay without any sample processing. Thus, simple immunoassays are particularly promising tools for fast screening of large number of samples.

However, the available immunoassays (including commercial ones) for microcystin and/or nodularin are generally in the form of competitive format [13] as usual with immunoassays for low molecular weight targets (MW less than $2000 \mathrm{Da}$ ). Relying on one antibody recognition site, competitive assays are time consuming (2-3 h), requiring several incubation and washing steps, which must be strictly maintained. Furthermore, the generated signal is inversely proportional to the analyte concentration, which can complicate the interpretation of the result.

We have previously reported the development of sensitive noncompetitive immunocomplex principle-based immunoassays for microcystin/nodularin $[14,15]$. These assays utilize a unique antibody pair consisting of a monoclonal antibody binding to the adda group common in microcystin and nodularin, and an antiimmunocomplex (anti-IC) single-chain antibody fragment (scFv) recognizing the anti-adda monoclonal antibody (Mab) when bound to basically any microcystin or nodularin (at least those 11 tested so far) [14]. This unique generic anti-IC scFv was isolated from our synthetic antibody library $[16,17]$ by phage display. Both the previously developed assays $[14,15]$ are heterogeneous in nature, requiring an intermediate washing step to remove the unbound components before the signal development step.

Homogeneous immunoassays lacking the washing or separation steps are very appealing detection tools as they provide significant advantages regarding simplicity, rapidity, and less instrumentation requirement. As previously demonstrated by Pulli et al. [18] and Arola et al. [19], the fact that the two antibodies involved in the immunocomplex-based recognition of a low molecular weight analyte are inevitably brought into very close interaction provides an excellent basis for the utilization of the fluorescence/Förster resonance energy transfer (FRET) process for the signal generation in a homogeneous assay $[20,21]$. In the FRET process, energy is transferred from a light-excited donor fluorophore through a dipoledipole coupling interaction to an acceptor fluorophore, which then releases the energy as light at higher wavelength $[20,22$, 23]. As the efficiency of the FRET process is highly dependent on the distance, being inversely proportional to the sixth power of it, the efficient energy transfer can typically only occur when the fluorophores are situated not more than 1$10 \mathrm{~nm}$ apart. By having the two antibodies needed for the immunocomplex formation labeled with the donor and acceptor fluorophore, respectively, FRET signal is likely obtained upon the recognition of the analyte by the antibodies. In timeresolved fluorescence/Förster resonance energy transfer (TRFRET) [24], a lanthanide ion-containing chelate is used as the donor compound. Due to the long fluorescence lifetime of such compounds, even $>1000 \mu$ s [25], the FRET signal can be measured within an appropriate time window after the excitation, which helps to avoid interference due to the short lifetime auto-fluorescence or cross-talk between the fluorophores. This can result in significantly higher signalto-background ratios and eventually improved assay sensitivity as compared to the standard FRET process.

Here, we describe a TR-FRET-based homogeneous noncompetitive sandwich-type immunoassay for the detection of microcystin/nodularin using the aforementioned immunocomplex forming antibody pair: anti-adda Mab and anti-IC scFv (as fused to bacterial alkaline phosphatase). The assay enables us to have a sensitive and quantitative detection of microcystin/nodularin in a simple mix-and-measure approach, in a short time $(<15 \mathrm{~min})$. The assay is applicable for quantitative analysis of microcystin-LR with a sample detection limit of $\sim 0.3 \mu \mathrm{g} / \mathrm{L}$, satisfying the $\mathrm{WHO}$ guideline limit 
$(1 \mu \mathrm{g} / \mathrm{L})$, thus providing a powerful tool for rapid and sensitive screening for cyanobacterial cyclic peptide hepatotoxins.

\section{Materials and methods}

\section{Common materials and reagents}

Colorless assay buffer solution used in the TR-FRET assay, colored assay buffer used in assays other than the FRET assay, 96-well streptavidin-coated plates, wash concentrate for washing the 96-well plate, and enhancement solution to dissociate the lanthanide (europium) ion were from Kaivogen (Turku, Finland). MaxiSorp 96-well microtiter plates used in the FRET immunoassay were from Nunc A/S, Thermo Fisher Scientific (Roskilde, Denmark). Monoclonal antibody AD4G2 (adda specific) which binds microcystin or nodularin through the adda residue was purchased from Enzo Life Sciences, Inc. (USA). Bacterial anti-alkaline phosphatase polyclonal antibody (bAP Pab) purchased from LifeSpan Biosciences, Inc. (USA), was purified and labeled with europium (Eu-bAP Pab) to be used as a tracer in the immunocomplex (IC) assay based on time-resolved fluorescence (TRF) (referred here IC-TRF assay) according to an earlier report [14]. The near-infrared fluorescent label Alexa Fluor ${ }^{\circledR} 680$ succinimidyl ester (AF680) were purchased from Molecular Probes, Invitrogen (Thermo Fisher Scientific Inc.). The immunoassays were carried out in room temperature (RT) of around $23{ }^{\circ} \mathrm{C}$.

\section{Instruments}

Delfia Plateshake for the shakings of the 96-well plates, plate washer, and enhancement solution dispenser were from Wallac, PerkinElmer Life and Analytical Sciences (Finland). Protein concentration was measured by a NanoDrop ND1000 spectrophotometer (Thermo Fisher Scientific Inc.).

\section{Plate readers}

The luminescent signal of $\mathrm{Eu}(\mathrm{III})$ using time-resolved mode was measured by the multilabel counter Victor ${ }^{\mathrm{TM}} 1420$ (PerkinElmer Life Sciences, Finland) by applying default factory settings (excitation $340 \mathrm{~nm}$, emission $615 \mathrm{~nm}$, delay $400 \mu \mathrm{s}$, gate time $400 \mu \mathrm{s})$. For TR-FRET measurement, the instrument was installed with a red-sensitive photomultiplier tube (R4632, Hamamatsu Photonics, Hamamatsu, Japan) and 730-nm bandpass emission filter of 10-nm bandwidth and $70 \%$ transmission maximum (Nabburg, Interferenzoptik Elektronik GmbH, Germany). TR-FRET was measured at $730 \mathrm{~nm}$ using a 340-nm excitation wavelength. The delay time of $75 \mu$ s and the measurement window of $50 \mu$ s were used according to the previous reports [26-28].

\section{The donor (Eu-anti-adda Mab)}

An intrinsically luminescent seven-dentate europium (7dE u I I I ) chelate, [2,2', $2^{\prime \prime}, 2^{\prime \prime \prime}$ - [ [ 4 - [ ( 4 isothiocyanatophenyl)ethynyl]pyridine-2,6diyl]bis(methylenenitrilo)] tetrakis(acetato)-europium(III)], MW $674.46 \mathrm{~g} / \mathrm{mol}$ [29], was labeled with the anti-adda Mab to be used as a donor in the FRET assay (Fig. 1). The 7d-EuIII chelate was synthesized earlier in the University of Turku (28) according to a previously described method [29]. The antiadda Mab $(\sim 700 \mu \mathrm{g}=\sim 4.38 \mathrm{nmol})$ and a 100-fold molar excess of 7d-EuIII chelate were dissolved into a total volume of $438 \mu \mathrm{L}$ of $50 \mathrm{mM}$ carbonate buffer, $\mathrm{pH}$ 9.8. The labeling reaction was incubated overnight at $+4{ }^{\circ} \mathrm{C}$ protected from light. The labeled antibody (Eu-anti-adda $\mathrm{Mab}$ ) was purified with gel filtration using a Superdex 200 column and eluted in TSA buffer $(50 \mathrm{mM}$ Tris- $\mathrm{HCl}, 150 \mathrm{mM} \mathrm{NaCl}$, and $0.5 \mathrm{~g} / \mathrm{L}$ $\mathrm{NaN}_{3}$ ), pH 7.75. The chelate concentration in the labeled Euanti-adda Mab was measured by comparing the fluorescence of the purified product against a known Eu(III) standard. The labeled antibody concentration was estimated by assuming that $90 \%$ of the initial unlabeled antibody was recovered in the collected labeled antibody pool (monitored by absorbance at $280 \mathrm{~nm}$ ). In the purified product, DTPA (diethylenetriamine pentaacetate)-treated BSA (bovine serum albumin) was added to a final concentration of $0.1 \%$ and filtered through $0.22 \mu \mathrm{m}$ and stored at $+4{ }^{\circ} \mathrm{C}$.

\section{The acceptor}

\section{Anti-IC scFv-AP}

A unique anti-IC scFv SA51D1 binder [14] was previously isolated from synthetic ScFvP antibody library $[16,17]$ by applying phage display technology using immunocomplex (anti-adda Mab bound to microcystin-LR) in the selection process. The selection process and screening of this binder have been described earlier [14]. The scFv as fusion with bacterial alkaline phosphatase (scFv-AP) was expressed in Escherichia coli strain RV308 in laboratory scale (5 L) fermentation at $26{ }^{\circ} \mathrm{C}$. The scFv-AP was purified through ammonium sulfate precipitation, affinity chromatography (HisTrap Fast Flow Ni-NTA column, GE, USA), and size exclusion chromatography (Superdex 200 column, GE, USA) and eluted in TSA buffer, $\mathrm{pH}$ 7.5.

\section{Conjugations of anti-IC scFv-AP with acceptor fluorophore}

The anti-IC scFv-AP was labeled with the near-infrared fluorescent label Alexa Fluor 680 (AF680) to be used as an acceptor fluorophore in the FRET assay. The buffer of the purified $\mathrm{scFv}$-AP was changed into PBS buffer $\mathrm{pH} 7.4$ and then conjugated with AF680 using a reaction between the 
Fig. 1 An intrinsically luminescent seven-dentate europium (7d-EuIII) chelate, MW: $674.46 \mathrm{~g} / \mathrm{mol}$ [29] was used to label the anti-adda Mab to be used as a donor (Eu-anti-adda Mab) in the TR-FRET assay

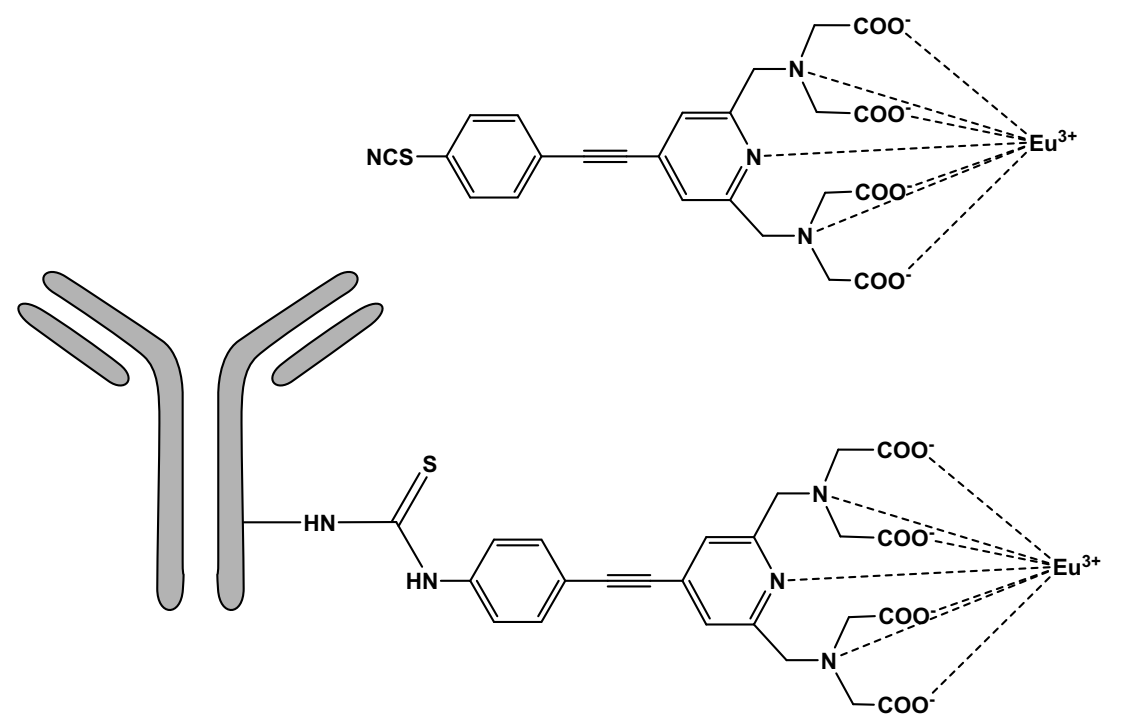

succinimidyl ester on the AF680 and the primary amino group on the scFv-AP. Aliquots of each $350 \mu \mathrm{g} \mathrm{scFv}$-AP were mixed with either $5,8,10$, or 15 -fold (batch $1,2,3$, and 4 , respectively) molar excess of AF680 (dissolved in N,Ndimethylformamide from Sigma-Aldrich) in $50 \mathrm{mM}$ carbonate buffer, $\mathrm{pH} 9.3$ in $500-\mu \mathrm{L}$ volume for $1 \mathrm{~h}$ at room temperature. The labeled products were purified by double gel filtration using NAP5 and NAP10 columns (GE Healthcare, UK) and eluted in TSA buffer, $\mathrm{pH}$ 7.5. According to the manufacturer's instruction, labeled protein concentration $(\mathrm{M})$ was measured as $\left[\left(\mathrm{A}_{280}-\mathrm{A}_{679} \times 0.05\right) \times\right.$ dilution factor $] / 203,000$, where the molar extinction coefficient of $\operatorname{IgG}$ is approximately $203,000 \mathrm{~cm}^{-1} \mathrm{M}^{-1}$ and correction factor for absorption of the AF680 dye at $280 \mathrm{~nm}$ is 0.05 . The labeling degrees [ $\left(\mathrm{A}_{679} \times\right.$ dilution factor) / $(184,000 \times$ protein concentration $(\mathrm{M}))$ where the approximate molar extinction coefficient of the AF680 dye at $679 \mathrm{~nm}$ is $184,000 \mathrm{~cm}^{-1} \mathrm{M}^{-1}$ ] of the purified products were measured by absorbance together with appropriate wavelength and molar absorptivity of the AF680 (provided by the manufacturer). The absorption maximum for unconjugated AF680 dye (MW 1150) is $679 \mathrm{~nm}$ and the emission maximum is $702 \mathrm{~nm}$. For resulting AF680 conjugates, the theoretical absorption maximum is $684 \mathrm{~nm}$ and the emission maximum is $707 \mathrm{~nm}$.

\section{BSA coating of microtiter wells}

To prevent non-specific binding, low-fluorescence yellow 96well MaxiSorp microtitration plates (Nunc, Roskilde, Denmark) were coated with BSA with saturation solution containing 0.1\% BSA (Bioreba, Switzerland) in the presence of $0.1 \%(\mathrm{w} / \mathrm{v})$ Germall II (ISP, Wayne, NJ) and 3\% (w/v) trehalose (Sigma-Aldrich, St. Louis, MO) in 0.05 M Tris$\mathrm{HCl}, \mathrm{pH}$ 7.2. Briefly, $250 \mu \mathrm{L} /$ well of saturation solution was added and incubated for $1 \mathrm{~h}$ at room temperature with slow shaking followed by aspiration of liquid. Plates were dried for $2 \mathrm{~h}$ and stored at $+4{ }^{\circ} \mathrm{C}$ in a sealed bag until used in the FRET immunoassay.

\section{Homogeneous FRET assay and optimization of assay parameters}

The homogeneous assays were performed using 7d-EuIII chelate-labeled anti-adda Mab (Eu-anti-adda Mab) as a donor and fluorescent acceptor dye AF680 conjugated to anti-IC scFv-AP (AF680-scFv-AP) as an acceptor. In BSA-coated microtiter wells, toxin standard $(0-100 \mu \mathrm{g} / \mathrm{L}$ of microcystin/ nodularin) or sample was added followed by addition of reagent mixture (comprising Eu-anti-adda Mab and AF680$\mathrm{scFv}-\mathrm{AP}$ ). Wells were then incubated (in room temperature with low shaking), and upon excitation at $340 \mathrm{~nm}$, the sensitized emissions from AF680 generated by FRET were measured at $730 \mathrm{~nm}$ by a Victor instrument.

Combination of different amounts of Eu-anti-adda Mab (5$200 \mathrm{ng} / \mathrm{well})$ and AF680-scFv-AP (10-200 ng/well) in a reagent mixture, effect of incubation time (2-60 min), and effect of reaction volume $(60-100 \mu \mathrm{L})$ were tested on assay performance using microcystin-LR as standard. In addition, combination of different delay times (50-125 $\mu \mathrm{s})$ and measurement windows $(25-50 \mu \mathrm{s})$ were explored as measurement parameters.

Finally, in the optimized assay, $20 \mu \mathrm{L}$ of sample/standard was mixed with $60 \mu \mathrm{L}$ of reagent mixture (15 $\mathrm{ng}$ of Eu-antiadda Mab and 120 ng of AF680-scFv-AP per well) and incubated for $15 \mathrm{~min}$, and FRET measurement was carried out using $50 \mu$ s of measuring time with $75 \mu$ s of delay time.

The detection limit (the smallest detectable toxin concentration in the sample) was calculated from the standard curve based on the average response of blank +3 times standard deviation of the blank. Concentrations of 
unknown samples were determined from the standard curve with the help of Origin software (OriginLab Corporation, Wellesley Hills, USA).

\section{Performance of different AF680-labeled scFv-AP}

Four batches (batch 1, 2, 3, 4) of AF680-labeled scFv-AP (AF680-scFv-AP) were prepared using different excess $(5 \mathrm{x}$, $8 \mathrm{x}, 10 \mathrm{x}, 15 \mathrm{x}$ respectively) of AF680. All four batches of AF680-scFv-AP were compared for their performance in preliminary TR-FRET assay using microcystin-LR as standard. In BSA pre-coated plate, $80 \mu \mathrm{L}$ of reagent mixture containing Eu-anti-adda Mab $(0.25 \mu \mathrm{g} / \mathrm{mL})$ and each batch of AF680scFv-AP $(2.5 \mu \mathrm{g} / \mathrm{mL})$ were added in the presence of $20 \mu \mathrm{L}$ of microcystin-LR. In the final $100-\mu \mathrm{L}$ reaction volume, concentration range of microcystin-LR was $0-40 \mu \mathrm{g} / \mathrm{L}$. TR-FRET measurement was performed after $5,10,15,20,25$, and $30 \mathrm{~min}$ with the delay time of $75 \mu \mathrm{s}$ and the measurement window of $50 \mu \mathrm{s}$.

\section{Effect of incubation time on assay performance}

The effect of incubation time on the performance of TR-FRET assay was observed using microcystin-LR as standard in duplicate wells. The assay was performed in $80-\mu \mathrm{L}$ total reaction volume where $20 \mu \mathrm{L}$ of microcystin-LR standard and $60 \mu \mathrm{L}$ of reagent mixture were added. Microcystin-LR concentration in the final $80-\mu \mathrm{L}$ reaction well ranged from $0,0.05$, to $250 \mu \mathrm{g} / \mathrm{L}$. Signal was measured at different incubation time points: 2 min to $60 \mathrm{~min}$.

\section{Standard curves of different microcystin/nodularin variants}

A total of nine different purified microcystin variants and nodularin (microcystin-LR, 3-demethylmicrocystin-LR, microcystin-RR, 3-demethylmicrocystin-RR, microcystinYR, microcystin-LY, microcystin-LF, microcystin-LW, nodularin-R) were (final concentration range in the $80-\mu \mathrm{L}$ reaction well: $0-250 \mu \mathrm{g} / \mathrm{L}$ ) analyzed to determine the specificity profile of the homogeneous TR-FRET assay. Toxins in the form of a lyophilized dried powder were obtained from Dr. Jussi Meriluoto's Lab (Åbo Akademi University, Turku, Finland) which were initially dissolved in 50\% methanol (100-250 $\mu \mathrm{M}$ original stock). The successive working stocks and standard preparation were performed with reagent water. Toxin stocks were kept at $-20^{\circ} \mathrm{C}$ or $4{ }^{\circ} \mathrm{C}$.

\section{Heterogeneous IC-TRF assay}

To compare the performance of the homogeneous assay to a similar heterogeneous assay, the environmental samples were also measured using the previously reported IC-TRF assay [14]. The assay concept was previously described [14] and was performed here with the following modification. In streptavidin-coated microtiter wells (Kaivogen, Turku, Finland), microcystin-LR standard $(0-20 \mu \mathrm{g} / \mathrm{L})$ and water samples were added as $20 \mu \mathrm{L} /$ well in the presence of $60-\mu \mathrm{L}$ reagent mixture $(1 \mu \mathrm{g} / \mathrm{mL}$ of biotinylated anti-adda Mab, $1 \mu \mathrm{g} / \mathrm{mL}$ of scFv-AP, and $0.5 \mu \mathrm{g} / \mathrm{mL}$ of Eu-bAP Pab). The wells were incubated for $1 \mathrm{~h}$ at room temperature with slow shaking and washed four times. Then, $200 \mu \mathrm{L} /$ well of enhancement solution (Kaivogen, Turku, Finland) was added, and after 5-10-min incubation at room temperature with shaking, TRF of Eu signal was measured with a Victor 1420 multilabel counter (Wallac, PerkinElmer Life and Analytical Sciences) using standard europium protocol where excitation wavelength was $340 \mathrm{~nm}$ and measurement wavelength was $615 \mathrm{~nm}$.

\section{Detection of microcystin-LR from spiked water samples}

Reagent water (Millipore) from the laboratory and two raw water samples from different Finnish lakes (Paalijärvi, Riihimäki, Finland 5.8.2009 and Tuusulanjärvi, Tuusula, Finland 24.6.2009) were selected for spiking experiment. The collected environmental samples were stored at $-20{ }^{\circ} \mathrm{C}$ until use. Before spiking, all samples were tested for any possible presence of toxin by the heterogeneous IC-TRF assay [14]. Each sample was spiked with microcystin-LR (concentration range: $0,0.2,0.5,1,5,10 \mu \mathrm{g} / \mathrm{L}$ ). Toxin concentrations of the spiked and the corresponding unspiked water samples were measured by the TR-FRET assay using duplicate wells. The recovery was calculated as follows: $\% R=$ (spiked sample result by TR-FRET - unspiked sample result by IC-TRF assay)*100/known spike added concentration.

\section{Analysis of environmental water samples}

In total, 18 environmental samples collected during 2009 from Finland and Estonia [30] were analyzed by the developed TRFRET-based homogeneous sandwich assay. For each sample, there were two parallel sets. One set comprising raw water as such (containing extracellular and any cell-bound toxin) was measured with the current TR-FRET assay as well as with the previously reported heterogeneous IC-TRF-based immunoassay [14]. Stored $\left(-20^{\circ} \mathrm{C}\right)$ raw samples were thawed-freezethawed to release the cell-bound toxin and used in the immunoassay without any concentration or further processing steps.

Another set of parallel water samples was previously filtered, toxins were extracted from the collected cells, and aliquots were made. Commercial ELISA and LC-MS were previously performed to determine the extracted intracellular microcystin/nodularin concentration and reported earlier [30]. From this same extracted sample set, one subset of aliquots was stored at $-20{ }^{\circ} \mathrm{C}$ as dried form (the liquid was evaporated) until analysis by the current TR-FRET assay as 
well as by the heterogeneous IC-TRF immunoassay. Before analysis, the samples were reconstituted in reagent water accordingly based on known results [30].

\section{Results}

\section{The developed TR-FRET assay concept}

To develop the TR-FRET-based homogeneous assay for microcystin/nodularin, the broad specific anti-IC scFv as fused to bacterial alkaline phosphatase (AP) was labeled with AF680 fluorophore (AF680-scFv-AP) and the adda-specific monoclonal antibody with the $\mathrm{Eu}^{3+}$-chelate (Eu-anti-adda $\mathrm{Mab})$. Figure 2 shows the principle of the developed assay.

\section{Performance of different AF680-labeled scFv on MC LR standard curve}

In order to find a suitable labeling degree, four different batches of AF680-scFv-AP were prepared and compared for their performance in the TR-FRET assay using microcystin-LR as analyte $(0-40 \mu \mathrm{g} / \mathrm{L}$ in final $100-\mu \mathrm{L}$ reaction well). A graph representing 15-min incubation data is shown in Fig. 3. All the batches were found to be active and performed well in the homogeneous assay. Batch 2 labeled with $8 \mathrm{x}$ molar excess of AF680 performed best in terms of low background and highest signal/blank (S/B) ratio. The top three best performing label batches (labeling with $8 \mathrm{x}, 10 \mathrm{x}$, and $15 \mathrm{x}$ molar

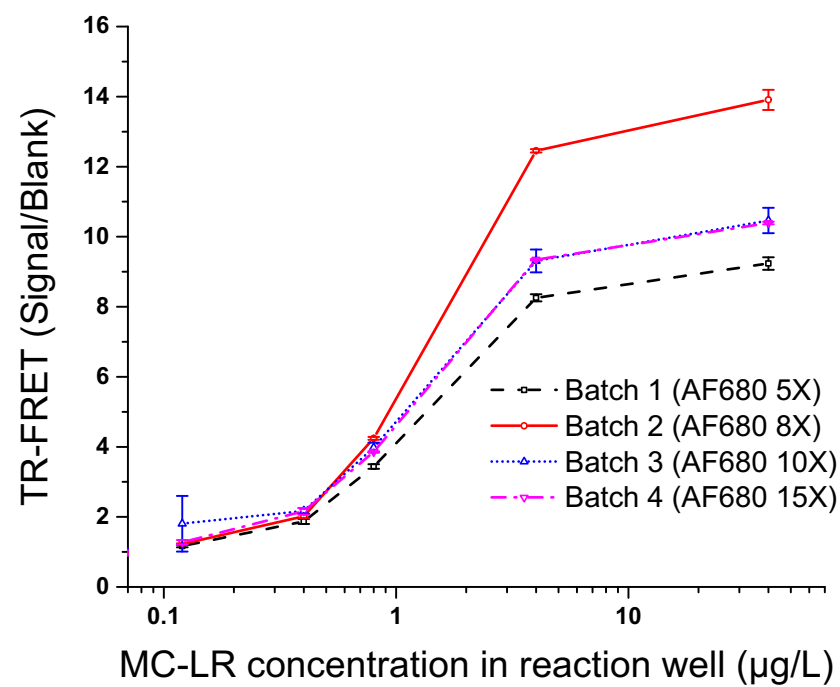

Fig. 3 TR-FRET signal to blank ratio of the homogeneous assay using different batches of AF680-labeled scFv-AP in the presence of microcystin-LR in total $100-\mu \mathrm{L}$ reaction well. TR-FRET measurement of the sensitized emission of AF680 at $730 \mathrm{~nm}$ was performed after 15min incubation. Error bar indicates the standard deviation (SD) of the value

excess of AF680) were utilized in the subsequent assays. When we compared the data in terms of signal/blank ratio, batch 2 likewise provided the highest $\mathrm{S} / \mathrm{B}$ ratio of 13.9 at $40 \mu \mathrm{g} / \mathrm{L}$ of microcystin-LR concentration. At the same toxin concentration, the rest of the label batches contributed similar S/B ratio (9.2 to 10.5). At lower concentration levels $(0.8 \mu \mathrm{g} / \mathrm{L}$ of microcystin-LR in reaction well), the performance ranking was batch $2(\mathrm{~S} / \mathrm{B} 4.2)>$ batch $3(\mathrm{~S} / \mathrm{B} 4)>$ batch $4(\mathrm{~S} / \mathrm{B}$ 3.9) $>$ batch 1 (S/B 3.4).
Fig. 2 The homogeneous noncompetitive TR-FRET immunoassay concept for cyanobacterial cyclic peptide hepatotoxins microcystin (MC) and nodularin (Nod). Eu-chelate-labeled addaspecific monoclonal antibody and AF680-labeled anti-IC scFv-AP are added together with water sample. In the absence of toxin in water sample (a), the antibodies are free in the solution and FRET is not detected. In the presence of toxin (b), the anti-IC scFv binds specifically to the immunocomplex of anti-adda Mab and MC/Nod, bringing the labels in close proximity.

Excitation of the Eu-chelate with UV light results in FRET between the labels, and sensitized emission of fluorescence signal can be detected at $730 \mathrm{~nm}$ in time-resolved mode a
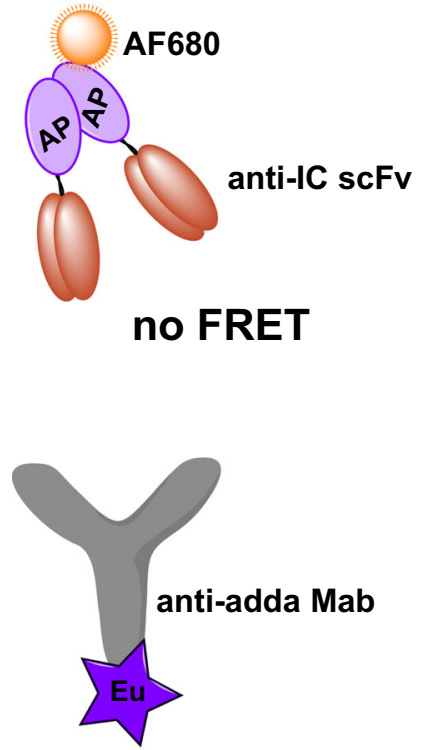

b

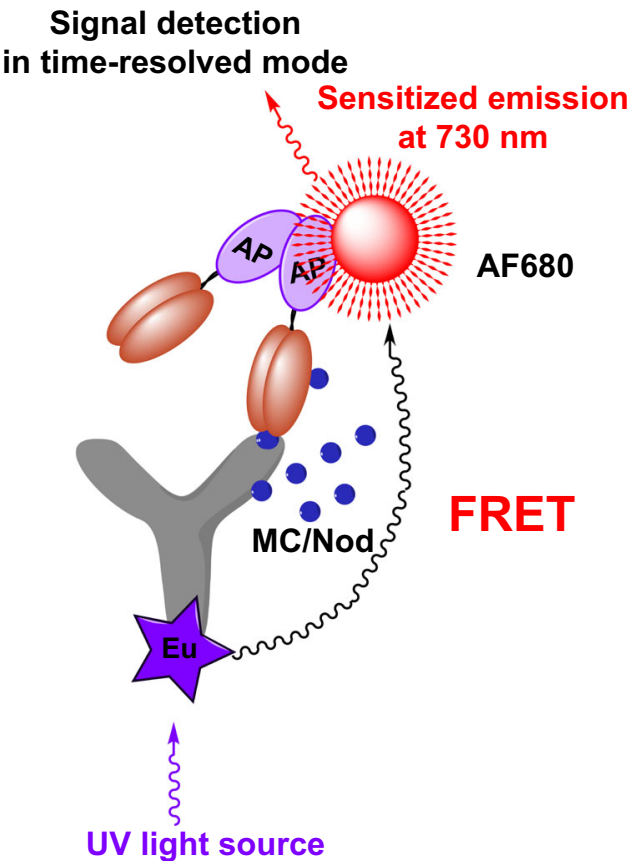




\section{Optimization of assay components and measurement parameters}

In order to optimize the reagent component in TR-FRET assay, varying amounts of Eu-anti-adda Mab (5-200 ng/well) and AF680-scFv-AP (10-200 ng/well) were evaluated in the assay in $\sim 100-\mu \mathrm{L}$ reaction well (see Supplementary Information (ESM), Fig. S1). Maximum average signals of 75,049 and 14,962 in the presence of $50 \mu \mathrm{g} / \mathrm{L}$ and $1 \mu \mathrm{g} / \mathrm{L}$ of microcystinLR respectively were achieved using the highest tested Mab and scFv amounts $(200 \mathrm{ng}+200 \mathrm{ng})$. However, in such case, the blank signal $(10,607)$ is also increased reducing the corresponding signal to background ratios $(\mathrm{S} / \mathrm{B})(7.1$ and 1.4 in the presence of $50 \mu \mathrm{g} / \mathrm{L}$ and $1 \mu \mathrm{g} / \mathrm{L}$ of microcystin-LR respectively). Decreasing amounts of Eu-Mab while maintaining the increased amount of AF680-scFv in a reaction well proportionately decreased the background signal. For example, with $20 \mathrm{ng}$ of Eu$\mathrm{Mab}+200$ ng of AF680-scFv, the S/B improved (15.2 and 4.8 in the presence of $50 \mu \mathrm{g} / \mathrm{L}$ and $1 \mu \mathrm{g} / \mathrm{L}$ of microcystin-LR respectively) more than twice. Several combinations of Eu-Mab + AF680-scFv provided S/B above 12 (at $50 \mu \mathrm{g} / \mathrm{L}$ of microcystin-LR) such as $10 \mathrm{ng} \mathrm{Eu}-\mathrm{Mab}+80$ to $160 \mathrm{ng}$ AF680-scFv or 20 ng Eu-Mab +160 to 200 ng AF680-scFv.

Subsequently, the total reaction volume of $60 \mu \mathrm{L}$, $80 \mu \mathrm{L}$, or $100 \mu \mathrm{L}$ was explored (Fig. 4) in the homogeneous assay using $15 \mathrm{ng}$ of Eu-Mab and $160 \mathrm{ng}$ of AF680-scFv. TR-FRET signal increased proportionately with the increase of reaction volume. Compared to S/B of $60 \mu \mathrm{L}$, the $\mathrm{S} / \mathrm{B}$ of $80-100 \mu \mathrm{L}$ was improved. However, the $\mathrm{S} / \mathrm{B}$ remained more or less similar in case of $80-\mu \mathrm{L}$ volume or $100-\mu \mathrm{L}$ volume. Better coefficient of variation $\%(\mathrm{cv} \%)$ of the signal from the duplicate measurements was achieved with $80-\mu \mathrm{L}$ (cv\% range: 0.7

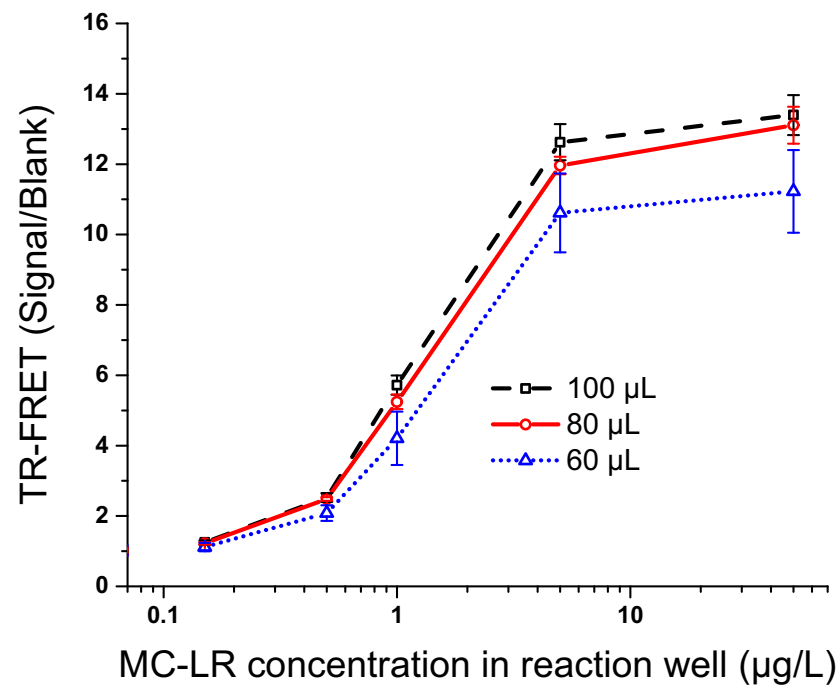

Fig. 4 Effect of total reaction volume in the microtiter well in the homogeneous assay using microcystin-LR as standard. Error bar indicates the standard deviation (SD) of the value to $3.5 \%$ ) or $100-\mu \mathrm{L}$ (cv\% range: 1.7 to $3.7 \%$ ) reaction volume, compared to the $60-\mu \mathrm{L}$ volume reaction wells (cv\% range: 2.5 to $14.9 \%$ ).

In the Victor fluorometer instrument, for TR-FRET measurement protocol, combination of different counting delay times $(50-125 \mu \mathrm{s})$, measurement window time $(25-50 \mu \mathrm{s})$, and flash energy level (EF; 130, 200, and default high 255) were explored to find out the suitable measurement parameters. Among these tested parameters [delay time/measurement window (EF)], measurement at 75/50 (EF high), 50/25 (EF high), and 75/25 (EF 200) seems to deliver best S/B.

Eventually, considering the signal level, S/B level, and acceptable $\mathrm{cv} \%$, in addition to minimal reagent consumption, in the subsequent experiments, $80-\mu \mathrm{L}$ reaction volume was used. In such condition, $20 \mu \mathrm{L}$ of sample/standard and $60 \mu \mathrm{L}$ of reagent component comprising $\sim 15 \mathrm{ng} /$ well of Eu-anti-adda Mab and $\sim 120 \mathrm{ng} /$ well of AF680-scFv-AP were used. The measurement protocol included flash energy level of 255 , counting delay time of $75 \mu \mathrm{s}$, and counting window time of $50 \mu \mathrm{s}$.

\section{Effect of incubation time}

The effect of incubation time on the performance of FRET assay (Fig. 5) was observed using microcystin-LR as standard (toxin concentration in $80-\mu \mathrm{L}$ reaction well: 0.05 to $250 \mu \mathrm{g} / \mathrm{L}$ ). Signal tends to increase up to $10-15$-min incubation. Incubating longer than $30 \mathrm{~min}$ does not have any beneficiary effect, rather the overall signal tends to drop. Longer incubation, such as $1 \mathrm{~h}$, reduces the total signal level at highest

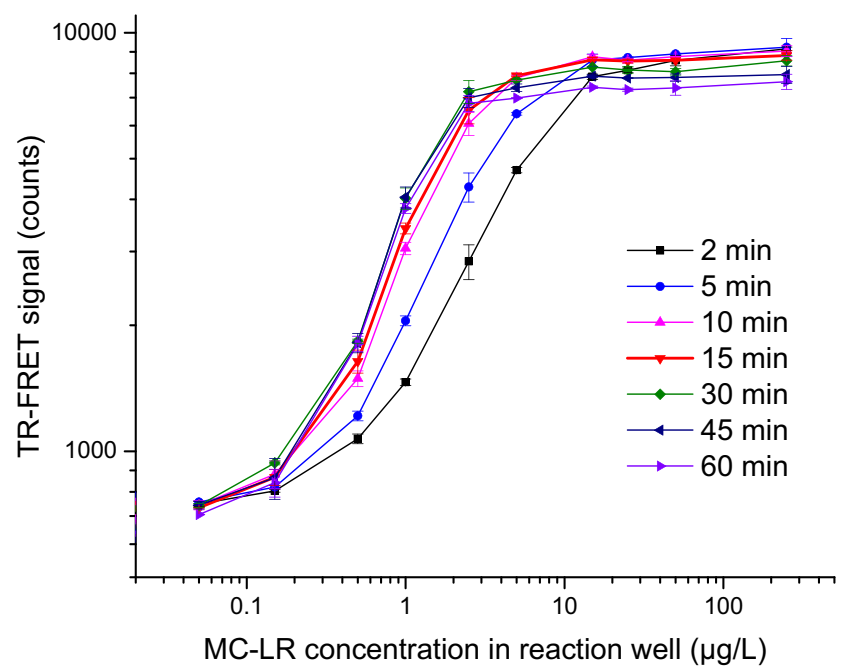

Fig. 5 Effect of incubation time on the homogeneous assay performance using microcystin-LR (MC-LR) as standard. In BSA-coated microtiter wells, MC-LR (final concentration in $80-\mu \mathrm{L}$ reaction well: 0.05 to $250 \mu \mathrm{g} / \mathrm{L}$, plotted in logarithmic scale in $X$ axis) was used to generate TR-FRET signal of the sensitized emission of AF680 at $730 \mathrm{~nm}$ (plotted in logarithmic scale in $Y$ axis) at different incubation time points (2$60 \mathrm{~min}$ ). Standard deviations of duplicate measurements are shown as error bar. Error bars are not visible when interfering with symbols 
concentration of standard curve. Based on these findings, 15min incubation time was used for further assays.

\section{Standard curves of different microcystin/nodularin variants}

Nine different purified toxin analogues [microcystin-LR, 3demethylmicrocystin-LR, microcystin-RR, 3demethylmicrocystin-RR, microcystin-YR, microcystin-LY, microcystin-LF, microcystin $-\mathrm{LW}$, and nodularin-R (final concentration range in $80-\mu \mathrm{L}$ reaction well: $0-250 \mu \mathrm{g} / \mathrm{L})$ ] were analyzed by the homogeneous assay, and the standard curves of the toxin variants are shown in Fig. 6. For the most important variant, microcystin-LR, based on average blank signal +3 times the standard deviation of 40 blank wells, sample detection limit of $\sim 0.3 \mu \mathrm{g} / \mathrm{L}(\sim 0.08 \mu \mathrm{g} / \mathrm{L}$ in reaction well) was achieved. For two other common congeners, microcystin-RR and microcystin-YR, the detection limit is similar or even better than that of microcystin-LR, respectively. For the rest of the microcystin variants and nodularin- $R$ sample, the detection limit is close to or below $1 \mu \mathrm{g} / \mathrm{L}$. As expected, due to the nature of the immunocomplex assay, no high-dose hook effect was observed, except for 3demethylmicrocystin-LR (dm-LR), in which case, some decrease in signal occurs at concentration above $25 \mu \mathrm{g} / \mathrm{L}$.

\section{Recovery with spiked water sample}

Reagent water and two Finnish lake water samples (Paalijärvi and Tuusulanjärvi) were used for spiking with microcystin$\mathrm{LR}$ at concentrations 0 to $10 \mu \mathrm{g} / \mathrm{L}$. In the non-spiked lake waters, some amount of toxin (extracellular and/or

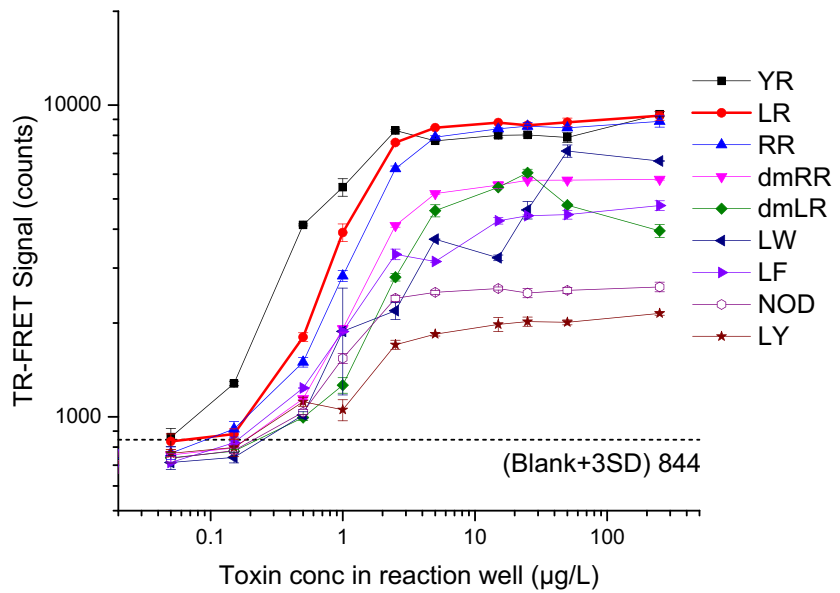

Fig. 6 Standard curves of eight different microcystin variants and nodularin-R in the TR-FRET assay. Toxin concentrations in total 80$\mu \mathrm{L}$ reaction well $(0.05$ to $250 \mu \mathrm{g} / \mathrm{L})$ are plotted in logarithmic scale in $X$ axis vs the corresponding TR-FRET signal (sensitized emission of AF680 at $730 \mathrm{~nm}$ ) in logarithmic scale in $Y$ axis. Standard deviations of duplicate measurements are shown as error bar. Error bars are not visible when interfering with symbols intracellular toxin) was detected (Paalijärvi: $0.09 \mu \mathrm{g} / \mathrm{L}$ and Tuusulanjärvi: $0.17 \mu \mathrm{g} / \mathrm{L}$ ) according to IC-TRF assay [14]. The spiked water was used in the TR-FRET immunoassay directly without any concentration or further dilution steps. Table 1 shows the measured toxin concentration and the recovery percentage of the sample by the TR-FRET measurements. While the TR-FRET assay was, as expected, not able to detect the lowest spiked toxin concentration $(0.2 \mu \mathrm{g} / \mathrm{L})$, the recoveries from samples spiked with 0.5 to $10 \mu \mathrm{g} / \mathrm{L}$ toxin were satisfactory and ranged from 65 to $123 \%$. For these samples, the coefficient of variation ( $\mathrm{cv} \%$ ) of TR-FRET measurement was also in the acceptable range ( 2 to $20 \%$ ). The results clearly demonstrated that the assay is applicable for measuring water sample below and near the WHO guideline value $(1 \mu \mathrm{g} / \mathrm{L}$ of microcystin-LR) for drinking water.

\section{Environmental sample analysis}

A total of 18 environmental water samples collected from Åland island of Finland, mainland Finland, and Estonia were analyzed with the TR-FRET and heterogeneous IC-TRF assays to determine the microcystin/nodularin concentration present in the natural raw water (intracellular and extracellular) as well as in the extracted sample (intracellular). The results are shown in the Table 2. Before analysis, each raw water samples were frozen and thawed at least twice to release any possible intracellular toxin in the water. For each sample, a corresponding parallel lyophilized sample set comprising extracted intracellular toxin was available which was reconstituted by water and analyzed also by TR-FRET and IC-TRF assays. For these samples, intracellular toxin concentration results by LC-MS were also available from a previous publication [30]. Amount of toxin in raw water was higher than the extracted intracellular toxin in many samples. This is an expected phenomenon as the raw water contains both the cellular toxin and the already released extracellular toxin. Good correlation was found between TR-FRET and the reference measurement assays. For toxin measurement from raw water, the coefficient of determination $\left(r^{2}\right)$ between TR-FRET and IC-TRF assay was as high as 0.99 . For intracellular toxin measurement, $r^{2}$ was 0.73 and 0.75 in respect to IC-TRF assay and LC-MS analysis, respectively.

\section{Discussion}

For detection of microcystin or nodularin, compared to the highly expensive high-performance liquid chromatography (HPLC) - or liquid chromatography-mass spectrometry (LCMS)-based methods, immunoassay-based methods offer advantages in terms of simplicity, cost-effectiveness, and wide accessibility. Furthermore, since raw water can be directly used, immunoassays are especially suitable for handling of 
Table 1 Analysis of toxin-spiked water samples by TR-FRET assay

\begin{tabular}{|c|c|c|c|c|c|c|c|c|c|}
\hline \multirow[b]{2}{*}{$\begin{array}{l}\text { MC-LR added } \\
\text { to the sample } \\
(\mu \mathrm{g} / \mathrm{L})\end{array}$} & \multicolumn{3}{|l|}{ MQ } & \multicolumn{3}{|c|}{ Paalijärvi (5.8.2009) } & \multicolumn{3}{|c|}{ Tuusulanjärvi (24.6.2009) } \\
\hline & $\begin{array}{l}\text { Toxin conc by } \\
\text { TR-FRET } \\
(\mu \mathrm{g} / \mathrm{L})\end{array}$ & $\begin{array}{l}\text { Recovery } \\
(\%)\end{array}$ & $\begin{array}{l}\mathrm{CV} \\
(\%)\end{array}$ & $\begin{array}{l}\text { Toxin conc by } \\
\text { TR-FRET } \\
(\mu \mathrm{g} / \mathrm{L})\end{array}$ & $\begin{array}{l}\text { Recovery } \\
(\%)\end{array}$ & $\begin{array}{l}\mathrm{CV} \\
(\%)\end{array}$ & $\begin{array}{l}\text { Toxin conc by } \\
\text { TR-FRET } \\
(\mu \mathrm{g} / \mathrm{L})\end{array}$ & $\begin{array}{l}\text { Recovery } \\
(\%)\end{array}$ & $\begin{array}{l}\mathrm{CV} \\
(\%)\end{array}$ \\
\hline 0 & $>\mathrm{dl}$ & - & - & $>\mathrm{dl}(0.9) \mathrm{a}$ & - & - & $>\mathrm{dl}(0.17) \mathrm{a}$ & - & - \\
\hline 0.2 & $>\mathrm{dl}$ & - & - & $>\mathrm{dl}$ & - & - & $>\mathrm{dl}$ & - & - \\
\hline 0.5 & 0.6 & 115 & 9 & 0.6 & 101 & 15 & 0.5 & 65 & 20 \\
\hline 1 & 1.0 & 96 & 9 & 1.1 & 99 & 6 & 1.2 & 100 & 16 \\
\hline 5 & 5.0 & 100 & 2 & 5.3 & 105 & 2 & 5.8 & 113 & 2 \\
\hline 10 & 11 & 110 & 8 & 12.1 & 121 & 6 & 12.5 & 123 & 14 \\
\hline
\end{tabular}

Coefficient of variations $\%$ (cv \%) are of two replicate measurements. >dl (below detection limit); a, toxin concentration detected according to IC-TRF assay [14]

large number of samples. Currently, several immunoassays for microcystins and nodularins are commercially available targeting the generic adda residue or specifically targeting the most common microcystin-LR [13, 31]. However, most of the available immunoassays are based on non-competitive methods that require several incubation and washing steps and hence consume several hours to complete the assays.
Possibility of reduced assay time from hours to minutes while maintaining the sufficient sensitivity (for example below WHO guideline limit of $1 \mu \mathrm{g} / \mathrm{L}$ of microcystin for drinking water) translates into overall reduced cost as well as rapid decision-making possibilities in a critical situation.

Homogeneous immunoassays, avoiding washing/ separation and usually also reagent addition steps, are highly

Table 2 Microcystin/nodularin amount in the environmental water samples from Finland and Estonia

\begin{tabular}{|c|c|c|c|c|c|c|}
\hline \multirow[b]{3}{*}{ Sampling location } & \multirow[b]{3}{*}{ Date } & \multicolumn{2}{|c|}{$\begin{array}{l}\text { Total toxin (extracellular }+ \text { intracellular) } \\
(\mu \mathrm{g} / \mathrm{L})\end{array}$} & \multicolumn{3}{|c|}{ Intracellular toxin $(\mu \mathrm{g} / \mathrm{L})$} \\
\hline & & \multicolumn{2}{|l|}{ Raw water } & \multicolumn{3}{|c|}{ Toxin extracted from collected cell } \\
\hline & & TR-FRET & IC-TRF & TR-FRET & IC-TRF & LC-MS* [30] \\
\hline Godby träsk, Finström, Åland Islands, Finland & 28.7.2009 & 0.85 & 0.68 & 0.05 & 0.05 & 0 \\
\hline Vargata träsk, Lövö Island, Åland Islands, Finland & 28.7.2009 & 57.50 & 55.25 & 24.80 & 21.94 & 24.5 \\
\hline Nåtö hemviken, Nåtö Island, Åland Islands, Finland & 30.7.2009 & 10.80 & 9.99 & 13.02 & 26.42 & 8.6 \\
\hline Littoistenjärvi, Kaarina, Finland & 26.8.2009 & 5.41 & 5.08 & 16.13 & 7.48 & 5.2 \\
\hline Hauninen reservoir, Raisio, Finland & 9.6.2009 & 5.85 & 7.24 & 2.48 & 4.73 & 11.9 \\
\hline Hauninen reservoir, Raisio, Finland & 16.6.2009 & 10.18 & 12.08 & 4.56 & 11.35 & 23.6 \\
\hline Hauninen reservoir, Raisio, Finland & 4.8.2009 & 0.52 & 0.46 & 0.49 & 0.29 & 0.8 \\
\hline Hauninen reservoir, Raisio, Finland & 8.9 .2009 & 0.60 & 0.52 & 0.78 & 0.55 & 1.1 \\
\hline Tuusulanjärvi, Tuusula, Finland & 24.6.2009 & 0.13 & 0.06 & 0.02 & 0.04 & 0 \\
\hline Maaria reservoir, Turku, Finland & 28.7.2009 & 1.80 & 1.58 & 1.71 & 1.51 & 1.7 \\
\hline Savojärvi, Pöytyä, Finland & 7.8.2009 & 67.78 & 55.49 & 61.32 & 31.57 & 40.9 \\
\hline Maaria reservoir, Turku, Finland & 11.8.2009 & 1.44 & 1.61 & 0.70 & 0.64 & 0.87 \\
\hline Rusutjärvi, Tuusula, Finland & 26.8.2009 & 1.20 & 1.13 & 1.43 & 0.84 & 0.78 \\
\hline Rusutjärvi, Tuusula, Finland & 16.9.2009 & 2.15 & 1.49 & 2.06 & 1.39 & 1.1 \\
\hline Lake Peipus, Kauksi beach, Estonia & 25.8.2009 & 0.77 & 0.82 & 0.96 & 0.58 & 0.52 \\
\hline Lake Peipus, Rannapungerja beach, Estonia & 14.8 .2009 & 0.43 & 0.21 & 0.31 & 0.23 & 0.25 \\
\hline Lake Peipus, Remniku beach, Estonia & 14.8.2009 & 0.69 & 0.47 & 0.38 & 0.26 & 0.26 \\
\hline Lake Harku, Tallinn, Estonia & 6.8 .2009 & 1.20 & 1.03 & 1.66 & 1.27 & 1.41 \\
\hline
\end{tabular}

LC-MS results were adapted from Savela et al., 2014 [30] 
appealing approaches for chemical analytics providing possibilities for the development of simple, rapid, and often costeffective tools for the detection of specific analytes. In this study, we developed a homogeneous assay for the generic quantitative detection of microcystin and nodularin. This mix-and-measure-type assay combines the advantages of non-competitive immunocomplex-based recognition of the analyte with a sensitive TR-FRET measurement technology. Moreover, due to the unique recognition profile of the immunocomplex forming antibody pair used, the assay allows generic detection of microcystin/nodularin — a large group of related compounds.

The developed TR-FRET assays show maximal S/B ratio of between 10 and 15 , depending on the toxin congeners used. These values are significantly higher than those in the two previously reported immunocomplex conceptbased TR-FRET assays for morphine [18] and mycotoxin [19], where S/B values between 2 and 4 were observed. One of the factors helping to reach a good performance was the optimization of the labeling conditions for the acceptor-carrying antibody. Best performance was obtained using around 10-fold molar excess of the label. With lower excess, the labels apparently are less likely to hit the sites being at good distance for FRET in the immunocomplex, whereas with higher excess, the selfquenching between the closely located labels probably decreases the FRET efficiency. With the anti-adda Mab, relatively high Eu-labeling degree of 5.5 was obtained by using $1.6 \mathrm{mg} / \mathrm{mL}$ Mab and 100x molar excess of Eu-chelate. In theory, maximizing the number of Eu-chelates per antibody would be beneficial for FRET as the fluorescence of Eu-chelates is not prone to self-quenching. However, we decided not to try any further to increase the labeling degree due to the risk of affecting binding properties of the antibody. Indeed, another factor affecting the S/B ratio is the binding affinities of the antibodies involved in the immunocomplex formation. Good functionality of our assay is also reflected as the high sensitivity of detection, which, e.g., for microcystin-LR is $\sim 0.3 \mu \mathrm{g} / \mathrm{L}$, meeting the WHO guideline limit for microcystins in drinking water.

The assay facilitates rapid measurement; after mixing the reagents with the sample, the signal reaches saturation in 10-15-min incubation at RT. However, already after 2min incubation, the signal for $1 \mu \mathrm{g} / \mathrm{L}$ of microcystin-LR can be reliably distinguished (Fig. 5). Compared to our previously reported heterogeneous immunoassay for microcystin/nodularin [14], the advantages of the present homogeneous assay include lower sample usage, together with reduced manual work and instrumentation requirements. The assay provides clear advantages for the screening of a large number of samples. However, such a simple and rapid homogeneous assay would, in theory, also very well lend itself for the analysis of individual samples in the field conditions. Concerning this, the main obstacle is the limited availability of portable instruments for the TRFbased measurements.

In comparison to our heterogeneous IC-TRF assay [14], there is more variation in relative signal levels obtained for different toxin congeners in the homogeneous assay. Especially, the signal for nodularin- $\mathrm{R}$ is clearly lower than that of microcystins. The results can potentially reflect somewhat lower affinities between the immunocomplex components in the case of nodularin-mediated interaction. Alternatively, the nodularin-mediated interaction might lead to the somewhat different orientation of the interacting antibodies compared to microcystin-based interaction, and the resulting changes in the relative positions for the FRET labels can affect the efficacy of the FRET. In any case, the homogeneous assay could recognize all the tested toxin variants (microcystin-LR, 3-demethylmicrocystin-LR, microcystinRR, 3-demethylmicrocystin-RR, microcystin-YR, microcystin-LY, microcystin-LF, microcystin -LW, nodularin-R) and most importantly the most toxic and widely reported microcystin-LR variant.

For the practical assessment of the assay, microcystinLR-spiked water (Table 1) and 18 true environmental water samples (Table 2) were analyzed and the results were compared to those obtained with reference methods (ICTRF assay and LC-MS). The toxin concentration measured by the TR-FRET assay correlates well with other methods indicating the practical applicability of the assay for the assessment of toxin levels in both direct environmental water and the cell-extracted samples. Overall, water is a very favorable sample matrix for homogeneous FRET-based measurement as it does not, in contrast to, e.g., blood-based sample matrixes, by default contain intensively light-absorbing compounds which could interfere with the excitation, emission, or dipole-dipole coupling-based energy transfer processes in a FRETbased assay. However, should a water sample for some reason have an unusually strong color, a few different dilutions of the samples could, for safety's sake, be analyzed.

\section{Conclusions}

The presented generic and quantitative homogeneous assay is sensitive enough to be employed in screening of water samples for microcystins below WHO guideline value of drinking water $(1 \mu \mathrm{g} / \mathrm{L})$ and recreational water 
(24 $\mu \mathrm{g} / \mathrm{L})$. The performance of the assay was demonstrated by analyzing the toxin-spiked sample and real environmental water samples. Being simple and rapid, this mix-and-measure-type assay should be applicable for the analysis of large numbers of water samples for microcystin or nodularin levels. It should also be wellsuited for automation and, hereby, useful for highthroughput screening applications.

Supplementary Information The online version contains supplementary material available at https://doi.org/10.1007/s00216-021-03375-8.

Acknowledgements We thank Dr. Jussi Meriluoto (Åbo Akademi University, Turku, Finland) for providing cyanotoxin reference materials and Markus Vehniäinen (currently in Biovian Ltd., Turku, Finland) for purifying the scFv-AP. We thank all the colleagues who collected samples: Sonja Nybom (Åbo Akademi University), Pirkko Ala-Uotila (Raisio-Naantali Waterworks), Pirkko Pajakko (Turku Municipal Water Company), Marko Järvinen (Finnish Environment Institute), Kirsti Lahti (Water Protection Association of the River Vantaa and Helsinki Region), and Aune Annus and coworkers (Tervisekaitse, Estonia). We thank Dr. Ulla Karhunen (currently in University of Eastern Finland) for helpful discussion during initial FRET assay setup.

Author contribution Conceptualization: Sultana Akter and Urpo Lamminmäki; methodology: Sultana Akter; formal analysis and investigation: Sultana Akter; writing — original draft preparation: Sultana Akter; visualization: Sultana Akter; writing - review and editing: Sultana Akter and Urpo Lamminmäki; funding acquisition: Sultana Akter and Urpo Lamminmäki; supervision: Urpo Lamminmäki. Both authors read and approved the final manuscript.

Funding Open access funding provided by University of Turku (UTU) including Turku University Central Hospital. This work was supported by the personal research grant (Wallac Fund from Turku University Foundation) towards Sultana Akter.

\section{Declarations}

Ethical approval This article does not contain any studies with human participants or animals performed by any of the authors.

Conflict of interest S. Akter and U. Lamminmäki are inventors in a granted patent (US20190010218) and in a pending patent application (WO2017109290) regarding the anti-immunocomplex antibody used in the manuscript. The assignee of the application is the University of Turku.

Open Access This article is licensed under a Creative Commons Attribution 4.0 International License, which permits use, sharing, adaptation, distribution and reproduction in any medium or format, as long as you give appropriate credit to the original author(s) and the source, provide a link to the Creative Commons licence, and indicate if changes were made. The images or other third party material in this article are included in the article's Creative Commons licence, unless indicated otherwise in a credit line to the material. If material is not included in the article's Creative Commons licence and your intended use is not permitted by statutory regulation or exceeds the permitted use, you will need to obtain permission directly from the copyright holder. To view a copy of this licence, visit http://creativecommons.org/licenses/by/4.0/.

\section{References}

1. Grosse Y, Baan R, Straif K, Secretan B, El Ghissassi F, Cogliano V, et al. Carcinogenicity of nitrate, nitrite, and cyanobacterial peptide toxins. Lancet Oncol. 2006;7(8):628-9.

2. Žegura B, Štraser A, Filipič M. Genotoxicity and potential carcinogenicity of cyanobacterial toxins - a review. Mutat Res Rev Mutat Res. 2011;727(1-2):16-41.

3. Buratti FM, Manganelli M, Vichi S, Stefanelli M, Scardala S, Testai E, et al. Cyanotoxins: producing organisms, occurrence, toxicity, mechanism of action and human health toxicological risk evaluation. Arch Toxicol. 2017;91(3):1049-130.

4. Svirčev Z, Drobac D, Tokodi N, Mijović B, Codd GA, Meriluoto J. Toxicology of microcystins with reference to cases of human intoxications and epidemiological investigations of exposures to cyanobacteria and cyanotoxins. Arch Toxicol. 2017;91(2):621-50.

5. Stewart I, Seawright AA, Shaw GR. Cyanobacterial poisoning in livestock, wild mammals and birds-an overview. Adv Exp Med Biol. 2008;619:613-37.

6. Svirčev Z, Lalić D, Bojadžija Savić G, Tokodi N, Drobac Backović $\mathrm{D}$, Chen L, et al. Global geographical and historical overview of cyanotoxin distribution and cyanobacterial poisonings. Arch Toxicol [internet]. 2019;93(9):2429-2481. Available from: https:// doi.org/10.1007/s00204-019-02524-4.

7. Bouaicha N, Miles CO, Beach DG, Labidi Z, Djabri A, Benayache NY, et al. Structural diversity, characterization and toxicology of microcystins. Toxins (Basel). 2019;11(12).

8. Catherine A, Bernard C, Spoof L, Bruno M. Microcystins and nodularins. Handb Cyanobacterial Monit Cyanotoxin Anal 1st ed; Meriluoto, J, Spoof, L, Cood, GA, Eds. 2017;109-26.

9. Chorus I, Welker M. Toxic cyanobacteria in water: a guide to their public health consequences, monitoring and management. CRC Press; 2021.

10. Chen G, Wang L, Wang M, Hu T. Comprehensive insights into the occurrence and toxicological issues of nodularins. Mar Pollut Bull [Internet]. 2021;162:111884 Available from: https://www. sciencedirect.com/science/article/pii/S0025326X2031002X.

11. Chorus I, Bartram J. Toxic cyanobacteria in water: a guide to their public health consequences, monitoring and management [internet]. London, UNITED KINGDOM: Taylor \& Francis Group; 1999. Available from: http://ebookcentral.proquest.com/lib/kutu/ detail.action?docID $=171763$

12. Msagati TAM, Siame BA, Shushu DD. Evaluation of methods for the isolation, detection and quantification of cyanobacterial hepatotoxins. Aquat Toxicol. 2006;78(4):382-97.

13. Weller MG. Immunoassays and biosensors for the detection of cyanobacterial toxins in water. Sensors (Switzerland). 2013;13(11):15085-112.

14. Akter S, Vehniäinen M, Spoof L, Nybom S, Meriluoto J, Lamminmäki U. Broad-spectrum noncompetitive immunocomplex immunoassay for cyanobacterial peptide hepatotoxins (microcystins and nodularins). Anal Chem. 2016;88(20):10080-7.

15. Akter S, Vehniäinen M, Meriluoto J, Spoof L, Lamminmäki U. Non-competitive ELISA with broad specificity for microcystins and nodularins. Adv Oceanogr Limnol. 2017;8(1).

16. Huovinen T, Syrjänpää M, Sanmark H, Brockmann E-C, Azhayev A, Wang Q, et al. Two ScFv antibody libraries derived from identical VL-VH framework with different binding site designs display distinct binding profiles. Protein Eng Des Sel. 2013;26(10):683-93.

17. Brockmann E-C, Akter S, Savukoski T, Huovinen T, Lehmusvuori A, Leivo J, et al. Synthetic single-framework antibody library integrated with rapid affinity maturation by VL shuffling. Protein Eng Des Sel. 2011;24(9):691-700. 
18. Pulli T, Höyhtyä M, Söderlund H, Takkinen K. One-step homogeneous immunoassay for small analytes. Anal Chem. 2005;77(8): $2637-42$.

19. Arola HO, Tullila A, Kiljunen H, Campbell K, Siitari H, Nevanen TK. Specific noncompetitive immunoassay for HT-2 mycotoxin detection. Anal Chem. 2016;88(4):2446-52.

20. Algar WR, Hildebrandt N, Vogel SS, Medintz IL. FRET as a biomolecular research tool — understanding its potential while avoiding pitfalls. Nat Methods [Internet] 2019;16(9):815-829. Available from: https://doi.org/10.1038/s41592-019-0530-8

21. Qiu X, Hildebrandt N. A clinical role for Förster resonance energy transfer in molecular diagnostics of disease. Expert Rev Mol Diagn [internet]. 2019;19(9):767-771. Available from: https://doi.org/10. 1080/14737159.2019.1649144.

22. Förster T. Zwischenmolekulare energiewanderung und fluoreszenz. Ann Phys. 1948;437(1-2):55-75.

23. Hildebrandt N. How to apply FRET: from experimental design to data analysis. FRET - Förster Reson Energy Transf From Theory to Appl 2013;105-163.

24. Zwier JM, Hildebrandt N. Time-Gated FRET Detection for multiplexed biosensing. In: Geddes CD, editor. Reviews in fluorescence 2016 [internet]. Cham: Springer International Publishing; 2017. p. 17-43. Available from: https://doi.org/10.1007/978-3319-48260-6 3.

25. Geibler D, Niko H. Lanthanide complexes in FRET applications. Curr Inorg Chem. 2011;1:17-35.
26. Kokko T, Liljenbäck T, Peltola MT, Kokko L, Soukka T. Homogeneous dual-parameter assay for prostate-specific antigen based on fluorescence resonance energy transfer. Anal Chem. 2008;80(24):9763-8.

27. Kokko L, Sandberg K, Lövgren T, Soukka T. Europium(III) chelate-dyed nanoparticles as donors in a homogeneous proximity-based immunoassay for estradiol. Anal Chim Acta. 2004;503(2):155-62.

28. Karhunen U, Rosenberg J, Lamminmäki U, Soukka T. Homogeneous detection of avidin based on switchable lanthanide luminescence. Anal Chem. 2011;83(23):9011-6.

29. Takalo H, Mukkala V-M, Mikola H, Liitti P, Hemmila I. Synthesis of europium (III) chelates suitable for labeling of bioactive molecules. Bioconjug Chem. 1994;5(3):278-82.

30. Savela H, Vehniäinen M, Spoof L, Nybom S, Meriluoto J, Lamminmäki U. Rapid quantification of mcyB copy numbers on dry chemistry PCR chips and predictability of microcystin concentrations in freshwater environments. Harmful Algae. 2014;39:2806.

31. Massey IY, Wu P, Wei J, Luo J, Ding P, Wei H, et al. A minireview on detection methods of microcystins. Toxins (Basel). 2020;12(10):1-32.

Publisher's note Springer Nature remains neutral with regard to jurisdictional claims in published maps and institutional affiliations. 